\title{
Editorial: The Relationship between International Humanitarian Law and General International Law
}

\author{
Lawrence Hill-Cawthorne* \& Kubo Mačák**
}

\section{General introduction}

International humanitarian law (IHL, also referred to as the law of war/armed conflict) is one of the oldest substantive areas of regulation under international law. As Sir Christopher Greenwood has noted,

... laws on the conduct of hostilities have existed in most cultures for hundreds, if not thousands, of years-rules prohibiting the use of certain weapons or prescribing the treatment of prisoners, for example, can be traced back to classical times-and international law has contained a law of war from the start. ${ }^{1}$

What is more, IHL has been present at many of the significant milestones in the modern history of public international law. It was with respect to war, for example, that many of the earliest multilateral treaties were adopted in the latter part of the nineteenth century. ${ }^{2}$ It was also the laws of war (alongside arms limitations and pacific settlement of disputes) on which the two Hague Peace Conferences of 1899 and 1907 focused, which had a profound impact on subsequent international conferences and the settlement of disputes throughout the twentieth century. ${ }^{3}$ In a similar way, the expansion of international law after the Second World War to regulate certain intra-State matters was realised, in part, in the field of armed conflict through the extension of conventional IHL to internal conflicts between States and non-State armed groups. ${ }^{4}$

This key place of the law of war in the historical development of the broader field of public international law is explained, in large part, by the relatively few specialised, substantive areas of regulation in international law at the time. Much has, of course, changed in this regard, given that over the last seventy years international law has expanded dramatically, now boasting a hugely diverse array of specialised fields. ${ }^{5}$ This potentially has consequences not only for the role of any single specialised field (such as IHL) in driving developments within public international law, but also on the scope of enquiry of much scholarship, which is now far more restricted as a result of

\footnotetext{
* Associate Professor in Public International Law, University of Reading. E-mail: 1.hill-cawthorne@reading.ac.uk.

** Senior Lecturer in Law, University of Exeter. E-mail: k.macak@exeter.ac.uk. The editors are grateful to Max Brookman-Byrne and Tomáš Morochovič for their research assistance.

${ }^{1}$ CJ Greenwood, 'The Law of War (International Humanitarian Law)' in MD Evans (ed), International Law (2nd edn, OUP 2006) 784. See also AV Lowe, International Law (OUP 2007) 282 ('[t]here is a substantial body of detailed rules on the conduct of hostilities. Such rules have existed for centuries'); JHW Verzijl, International Law in Historical Perspective, Vol IX, Part IX-A: The Laws of War (Sijthoff \& Noordhoff 1978) 1 (' $[\mathrm{t}]$ he laws of war have a long history. Prohibitions of specific methods of warfare, such as the poisoning of wells or the desecration of temples, can already be found in ancient legal sources').

2 A MacNair, 'The Functions and Differing Legal Character of Treaties' (1930) 11 BYIL 100, 105-6.

${ }^{3}$ B Baker, 'Hague Peace Conferences (1899 and 1907)' in R Wolfrum (ed), Max Planck Encyclopedia of Public International Law (2009).

${ }^{4}$ One of the present authors has explored this in detail elsewhere: L Hill-Cawthorne, 'Humanitarian Law, Human Rights Law, and the Bifurcation of Armed Conflict' (2015) 64 ICLQ 293.

${ }^{5} \mathrm{~T}$ Broude and Y Shany, 'The International Law and Policy of Multi-Sourced Equivalent Norms' in T Broude and Y Shany (eds), Multi-Sourced Equivalent Norms in International Law (Hart 2011) 3-4.
} 
the growing specialisation of each specific field within international law. Regarding IHL in particular, it has been remarked that this specialisation has resulted in it becoming

... one of the most highly focused areas of public international law and has hastened its omission from contemporary debate. Indeed, most general public international lawyers (if any truly still exist) would only claim a basic understanding of humanitarian law and, as such, are slower to engage with it than perhaps other sub-genres within the international legal order. ${ }^{6}$

It is against this background that this special issue of the Journal of Conflict \& Security Law explores the place of IHL within public international law, both historically and today. As a topic of enquiry, this is, of course, embedded within the rich and diverse literature on the fragmentation of international law. ${ }^{7}$ The overall aim of this issue is to consider how certain norms of general international law that apply across specialised fields (such as those regulating law creation, treaty interpretation, and State responsibility) have operated, or indeed evolved, in the field of IHL. ${ }^{8}$ This is an under-explored topic, and it is to be contrasted with the literature that explores the relationship between IHL and other specialised regimes of public international law, whether international human rights law (IHRL), ${ }^{9}$ international refugee law, ${ }^{10}$ or international investment law. ${ }^{11}$ It is, instead, closer in its approach to the edited collection by Professors Menno Kamminga and Martin Scheinin on the impact of human rights law on general international law, a result of the work on the topic by the International Law Association's Committee on International Law and Practice. $^{12}$

The articles in this special issue are the product of papers presented and commented upon at a two-day roundtable that was co-convened by ourselves and held at the University of Exeter in September $2016 .{ }^{13}$ The topic of that roundtable was, similarly to the Kamminga and Scheinin project, the impact of the law of armed conflict on general international law. However, in light of

6 A O'Donoghue, 'Splendid Isolation: International Humanitarian Law, Legal Theory, and the International Legal Order' (2011) 14 Ybk of IHL 107, 111.

7 See, eg, B Simma, 'Self-Contained Regimes' (1985) 16 Netherlands Yearbook of International Law 111; M Andenas and E Bjorge (eds), A Farewell to Fragmentation: Reassertion and Convergence in International Law (CUP 2015).

${ }^{8}$ The term 'general international law' is employed here in the following sense: 'General international law is a concept that is often used but rarely defined. It is the opposite of special international law (lex specialis), which governs particular topics (international trade law, law of the sea etc.). Examples of general international law are the law of treaties, as codified in the Vienna Convention on the Law of Treaties, and the law of state responsibility, as codified in the Articles on the Responsibility of States for Internationally Wrongful Acts'. MT Kamminga and M Scheinin (eds), The Impact of Human Rights Law on General International Law (OUP 2009) 2.

${ }^{9}$ See, eg, R Provost, International Human Rights and Humanitarian Law (CUP 2002); C Droege, 'Elective Affinities? Human Rights and Humanitarian Law' (2008) 90 IRRC 501; M Milanovic, 'A Norm Conflict Perspective on the Relationship Between International Humanitarian Law and Human Rights Law’ (2012) 23 EJIL 121; C De Koker and T Ruys, 'Foregoing Lex Specialis: Exclusivist v. Symbiotic Approaches to the Concurrent Application of International Humanitarian and Human Rights Law' (2016) 49 RBDI 244; M Hakimi, 'The Theory and Practice at the Intersection Between Human Rights and Humanitarian Law’ (2017) 111 AJIL 1063.

10 See, eg, V Chetail, 'Armed Conflict and Forced Migration: A Systemic Approach to International Humanitarian Law, Refugee Law, and Human Rights Law' in A Clapham and P Gaeta (eds), The Oxford Handbook of International Law in Armed Conflict (OUP 2014).

11 See, eg, GI Hernández, 'The Interaction between Investment Law and the Law of Armed Conflict in the Interpretation of Full Protection and Security Clauses' in F Baetens (ed), Investment Law within International Law: Integrationist Perspectives (CUP 2013).

12 Kamminga and Scheinin (n 8).

${ }^{13}$ For details of the workshop, see http:// socialsciences.exeter.ac.uk/law/research/projects/project/?id=579. We are very grateful to all participants at the roundtable for their valued contributions, as well as to the University of Exeter for funding the roundtable. 
the discussions, for the purposes of this special issue, the topic has been expanded to consider the relationship between the law of armed conflict and general international law more broadly.

The papers that follow thus all serve to explore the place of IHL within the broader field of pubic international law. By considering how a range of general international law issues regarding sources, State responsibility, and structural concepts such as State sovereignty arise in the specific field of IHL, a rich and complex relationship between IHL and general international law is revealed. Depending on the particular area, this relationship varies quite considerably, with a wide spectrum of different possibilities: first, in some areas, and consistent with the claim made above concerning its historical place, IHL has played a key role and impacted upon the development of general international law; ${ }^{14}$ second, IHL has functioned as a vital testing ground for certain general international law concepts; ${ }^{15}$ third, IHL and general international law have influenced one another symbiotically in particular respects ${ }^{16}$ fourth, IHL and general international law have diverged quite markedly in one particular respect; ${ }^{17}$ and fifth, IHL has contributed a more nuanced understanding of certain general international law concepts, creating possibilities for change in the future. ${ }^{18}$

Before moving on to an overview of each article in this special issue, one further theme should be noted that can be drawn out of all of these contributions taken together. This concerns the prominent role of non-State actors in IHL. The nature of IHL is such that much of its operation concerns non-State actors, including individuals as protected by its norms and non-State armed groups as bound by them. This necessarily means that the operation of certain general international law concepts in the field of IHL might be affected by the prominent role of non-State actors in that field. Indeed, a number of the articles in this special issue show how this feature of IHL might affect the relationship between this specific regime and general international law. ${ }^{19}$ The importance of non-State actors as rights-holders in other fields, such as human rights law and investment law, and calls to extend international law obligations to non-State actors beyond the limited fields in

$14 \mathrm{~V}$ Todeschini, 'The Impact of International Humanitarian Law on the Principle of Systemic Integration' (2018) 23(3) JCSL _ (IHL as reinvigorating and potentially expanding the so-called principle of systemic integration); A Berkes, 'The Standard of Due Diligence as a Result of Interchange between the Law of Armed Conflict and General International Law' (2018) 23(3) JCSL _ (IHL as a source of the concept of due diligence obligations); R Bartels, 'The Relationship between International Humanitarian Law and the Notion of State Sovereignty' (2018) 23(3) JCSL (armed conflict and IHL as drivers in altering State sovereignty as a structural concept in international law).

15 M Longobardo, 'The Contribution of International Humanitarian Law to the Development of the Law of International Responsibility Regarding Obligations Erga Omnes and Erga Omnes Partes' (2018) 23(3) JCSL _ (IHL treaties as early examples of obligations erga omnes partes and IHL as a field in which the now well-recognised consequences of such obligations for the right to invoke State responsibility for breaches were borne out).

${ }^{16}$ Berkes (n 14) (noting the influence of the general international law concept of due diligence on certain provisions of IHL).

${ }^{17}$ R Jorritsma, 'Where General International Law meets International Humanitarian Law: Attribution of Conduct and the Classification of Armed Conflicts' (2018) 23(3) JCSL _ (on the divergence between the International Criminal Tribunal for the former Yugoslavia's 'overall control' test for conflict classification and the International Court of Justice's related 'effective control' test for attribution of acts of non-State actors to States for the purposes of State responsibility).

${ }^{18}$ K Fortin, 'How to Cope with a Diversity while Preserving Unity in Customary International Law? Some Insights from International Humanitarian Law' (2018) 23(3) JCSL _ (on the different senses of generality of custom and the need to rethink our understanding of the role of different actors in custom formation).

19 Fortin, ibid (examining the degree to which the presence of non-State bearers of obligations under IHL has disrupted the traditional understandings of custom); Todeschini (n 14) (on the extension of the principle of systemic integration beyond the traditional inter-State realm); Berkes ( $\mathrm{n}$ 14) (on the extension of due diligence obligations to non-State actors); Bartels (n 14) (on the fundamental importance of obligations for non-State armed groups under IHL for the concept of State sovereignty). 
which this has already occurred, ${ }^{20}$ means that such conclusions are likely to extend beyond IHL, whether presently or in the future. ${ }^{21}$

\section{Overview of the contributions}

As noted, each article explores a different issue at the intersections between IHL and general international law. The first two contributions to this symposium consider particular aspects of the sources of law, and in the first article, Dr Katherine Fortin explores the tensions between the seemingly conflicting values of unity and diversity of international law. ${ }^{22}$ Her focus is on custom as one of the two principal sources of international law. ${ }^{23}$ In that regard, she notes that the generality of customary international law is an important legal glue that joins and unifies the international community of States'. ${ }^{24}$ However, she qualifies that statement at the outset by observing that the idea of unity that supposedly undergirds customary international law is in reality multifaceted.

In particular, strict unity would mean that a single class of actors (i.e., States) create and are bound by a single class of rules (i.e., customary international law): in Dr Fortin's terms, there would be a unity of law-makers, a unity of duty-bearers, and a unity of norms. ${ }^{25}$ However, there is little doubt that in a number of areas of international law, the purported unity of duty-bearers has been severely disrupted by the emergence of a diverse range of non-State actors. For instance, organized armed groups are generally considered to be bound by customary (and conventional) IHL. ${ }^{26}$ In other words, such entities now count among the duty-bearers, even though they most decidedly are not States. But does this streak of emerging diversity affect the other two 'unities'?

With regard to the unity of norms, Dr Fortin demonstrates that it would be anachronistic to insist that all customary rules must have an identical legal effect on all actors with international personality. Again, IHL offers a fertile ground to test this hypothesis and Dr Fortin lists a number of customary rules which apply to States and non-State armed groups in different ways. ${ }^{27}$ But at least in a certain sense, the unity of norms can nonetheless be said to have been preserved: the growing number of non-State entities bound by international law has not changed the fact that States still have 'the same general obligations to each other under general customary international law'. ${ }^{28}$

By contrast, States are much more resistant to any attempts to dilute the unity of law-makers. In this regard, Dr Fortin traces the debates on the propriety of accepting the practice and opinio juris of non-State actors for the purposes of custom formation. Her conclusion, based on a detailed analysis of the nature and conduct of armed groups, is close to the orthodox position: non-State

\footnotetext{
${ }^{20}$ See, eg, JG Ruggie, 'Business and Human Rights: The Evolving International Agenda' (2007) 101 AJIL 819.

21 As an example, see the claims that the general international law rules on reservations to treaties operate differently in the field of IHRL given their conferral of individual rights: UN Human Rights Committee, General Comment No 24, CCPR/C/21/Rev.1/Add.6, 4 November 1994, para 17.

${ }^{22}$ Fortin (n 18).

${ }^{23}$ Cf H Thirlway, The Sources of International Law (OUP 2014) 11 ('treaties and international custom are the two main sources of law').

${ }^{24}$ Fortin (n 18) _.

${ }^{25}$ Ibid

${ }^{26}$ See, eg, L Zegveld, The Accountability of Armed Opposition Groups in International Law (CUP 2002) 19; F Hampson, 'The Impact of the War on Terror on the Accountability of Armed Groups' in HM Hensel (ed), The Law of Armed Conflict: Constraints on the Contemporary Use of Military Force (Ashgate 2007) 158 fn 67; S Sivakumaran, The Law of NonInternational Armed Conflict (OUP 2012) 239.

27 See Fortin (n 18)

${ }^{28} \mathrm{Ibid} \_$_ (emphasis original).
} 
actors are too diverse, too disunited, and too transitory for their practice to be counted as equivalent to that of States. However, there is a nuance to be added. On the basis of her analysis of the role of armed groups in the creation and implementation of IHL, Dr Fortin cautions that we must find a way to involve non-State actors in shaping those norms that bind them-as otherwise we might jeopardize the authority and legitimacy of international law. ${ }^{29}$

The following contribution, continuing with the theme of sources, is authored by Dr Vito Todeschini who examines the impact that IHL has had on the development of the principle of systemic integration under general international law. ${ }^{30}$ The principle of systemic integration, as codified by Article 31(3)(c) of the Vienna Convention on the Law of Treaties (VCLT), requires that the interpretation of treaties must take into account ' $[a]$ ny relevant rules of international law applicable in the relations between the parties' ${ }^{31}$ Dr Todeschini explores the interaction between the relevant developments in IHL and the evolution of this principle under general international law.

In doing so, he engages in a detailed assessment of international jurisprudence that has invoked a variety of rules of IHL. His analysis reveals that the principle has been relied upon by a wide range of judicial and quasi-judicial bodies including the International Court of Justice (ICJ), the European Court of Human Rights, the Inter-American Court and Commission of Human Rights, and the International Criminal Court. Although not all of the studied decisions expressly refer to Article 31(3)(c) of the VCLT, they all share the idea that the relevant context of a given provision in a treaty is broader than the treaty of which it forms a part or even than the area of international law to which the treaty is said to belong. ${ }^{32}$

Dr Todeschini's analysis further confirms the close interplay between IHL and IHRL and offers a valuable contribution to our understanding of the relationship between these two areas. In that regard, he shows that international tribunals have used the principle in one of two mutually exclusive ways. Specifically, they have either done so to amplify the reach of human rights norms by finding a corresponding IHL norm that pulls in the same direction (convergent use)—or to avoid a potential norm conflict by prioritizing the rule of IHL that happens to be in tension with a rule of IHRL (divergent use). ${ }^{33}$

Dr Todeschini's article addresses the overarching aim of this special issue by identifying the specific forms of impact that the application of IHL in international jurisprudence has had on the general principle of systemic integration. The first of these is that these decisions have reinvigorated the principle after years of languishing and relative disuse. Today, there is a wealth of case-law illuminating our understanding of the principle, and much of it is related to IHL. Secondly, many of these cases have applied the principle in situations going beyond the traditional inter-State context foreseen by Article 31(3)(c) of the VCLT. In Dr Todeschini's summary, this therefore suggests that developments in the area of IHL may have broadened the principle of systemic integration beyond its codified formulation. ${ }^{34}$

\footnotetext{
${ }^{29}$ Ibid

30 Todeschini (n 14).

31 Vienna Convention on the Law of Treaties (concluded 23 May 1969, entered into force 27 January 1980) 1155 UNTS 331, Art 31(3)(c) (hereafter "VCLT").

32 Todeschini (n 14) _.

${ }^{33} \mathrm{Ibid}$

${ }^{34}$ Ibid
} 
The next three contributions examine the relationship between IHL and the law of State responsibility. The first is Dr Marco Longobardo's article, which explores the presence of obligations erga omnes and erga omnes partes in IHL. ${ }^{35}$ The notion of obligations erga omnes was originally recognized by the International Court of Justice (ICJ) in Barcelona Traction as a specific category of international obligations that a State may owe to 'the international community as a whole, in contradistinction to a traditionally bilateralised understanding of international law. ${ }^{36}$ Importantly, the notion was subsequently adopted by the International Law Commission (ILC) in its 2001 Articles on State Responsibility. ${ }^{37}$ The derived phrase 'erga omnes partes' refers to those obligations that are owed collectively to a group of States, typically because they are all parties to the same multilateral treaty. ${ }^{38}$

Dr Longobardo builds on this conceptual framework to argue that the notion of obligations erga omnes (partes) has been tried and tested in the field of IHL. He shows that core IHL treaties contain provisions that can be seen as comprising obligations erga omnes partes or even-insofar as the rules in question have crystallized into customary international law-obligations erga omnes. ${ }^{39}$ These include the obligation to respect and ensure respect for the Geneva Conventions; ${ }^{40}$ the obligations related to the system of Protecting Powers; ${ }^{41}$ the obligation to refrain from resort to belligerent reprisals against protected persons and objects; ${ }^{42}$ and others. ${ }^{43}$ On Dr Longobardo's analysis, what unites all of these provisions is that they indicate a non-bilateralised understanding of IHL that protects shared interests of the international community, with the concomitant obligations owed to the international community as a whole as opposed to States individually. ${ }^{44}$

He further examines relevant State practice regarding reactions to putative violations of IHL. This empirical overview catalogues a wide array of cases in which States not qualifying as injured States' (as that term is understood under the law of State responsibility) nonetheless invoke the responsibility of the wrongdoing State, resorting to the toolkit of responses available under the secondary rules. This analysis supports Dr Longobardo's claim that all States have a legal interest in compliance with IHL, which is in line with the designation of many IHL rules as comprising obligations erga omnes (partes). ${ }^{45}$ Overall, Dr Longobardo's piece provides an important example of a central concept of international law having been developed, in part, in the burgeoning field of IHL.

Mr Remy Jorritsma's article provides a fresh look at an issue that has been vexing international lawyers for almost two decades. ${ }^{46}$ Specifically, he examines the interplay between IHL and general

\footnotetext{
${ }^{35}$ Longobardo (n 15).

36 Barcelona Traction, Light and Power Company, Limited (Belgium v Spain) (Judgment) [1970] ICJ Rep 3, 32 [33].

${ }^{37}$ ILC, Articles on the Responsibility of States for Internationally Wrongful Acts, UN GA Res 56/83 annex, UN Doc A/ RES/56/83 (12 December 2001), Arts 33(1), 42(b), and 48(1)(b) (hereafter "ILC ASR").

${ }^{38}$ ILC ASR, ibid, commentary to Art 48, at para 6 ('obligations protecting a collective interest of the group may derive from multilateral treaties or customary international law. Such obligations have sometimes been referred to as "obligations erga omnes partes".').

${ }^{39}$ Longobardo (n 15) _.

${ }^{40}$ GCs, Common Art 1.

${ }^{41}$ See, in particular, GCs, Common Arts 8/8/8/9 and 10/10/10/11; AP I, Art 5.

42 See, in particular, GC I, Art 46; GC II, Art 47; GC III, Art 13(3); GC IV, Art 33(3); AP I, Arts 20, 51(6), 52(1), 53(c), 54(4), 55(2), 56(4).

${ }^{43}$ See Longobardo (n 15) _- _.

${ }^{44}$ Ibid

45 Ibid

46 See Jorritsma (n 17).
} 
international law regarding State responsibility for the conduct of proxy actors in time of armed conflict. It is well-known that two different legal tests have emerged in the international jurisprudence in this regard. While the ICJ established in Nicaragua the more demanding test of effective control, ${ }^{47}$ a line of cases of the ICTY that goes back to Tadic has advocated a less stringent test of overall control, ${ }^{48}$ resulting in lamentations that the law on point has become irreconcilably fragmented. ${ }^{49}$

Mr Jorritsma's main contribution is in his creative reinterpretation of the dilemma at the heart of the issue. Although he has to (and does) choose a side in the debate, he argues that the two positions are much less irreconcilable than many of their proponents have come to believe. He sides with those who take the view described in the article as one of 'functional equivalence', i.e. that rules on attribution must be coterminous with the determination of conflict characterisation under IHL. ${ }^{50}$ This is to be contrasted with the 'functional differentiation' approach, according to which the distinction between primary and secondary rules of international law means that the tests for attribution and conflict classification may be (and in fact are) different, because they serve fundamentally different functions under international law. ${ }^{51}$

Accordingly, Mr Jorritsma's position is that if the control that the outside State wields over a proxy actor is sufficient to make that State a party to an international armed conflict (IAC), then that same level of control is also sufficient for the purposes of attribution of the conduct of the proxy actor to the State. He argues that this follows from the very 'close connection' that exists between the two sets of rules in question..$^{52}$ He further posits that this reasoning shows that both courts were right to a degree: the ICTY in identifying a test that avoids a 'responsibility gap' and the ICJ in requesting that the test for conflict qualification be anchored in the primary rules of IHL. ${ }^{53}$ Not everyone will agree, of course, and the debate is likely to continue. ${ }^{54}$ However, scholars and practitioners will have to grapple with Mr Jorritsma's compelling reconciliation of the two legal tests.

In broader terms, this article also demonstrates that while the relationship between IHL and general international law may frequently bring the two bodies of law very close, this need necessarily not result in the impact of the former on the latter. Specifically with respect to the requirement of control under international law, Mr Jorritsma sums up that the less stringent overall control test developed in the context of IHL has not transcended the boundaries of that body of law. Rather, on his view, that test amounts to a lex specialis ${ }^{55}$ applicable solely to situations governed by IHL and without a direct impact on the general law of State responsibility. ${ }^{56}$

\footnotetext{
${ }^{47}$ Military and Paramilitary Activities in and against Nicaragua (Nicaragua v US) (Merits) [1986] ICJ Rep 14 [115].

48 Prosecutor v Tadic (Appeal Judgment) IT-94-1-A (15 July 1999) [131]; see also Prosecutor v Kordic and Cerkez. (Trial Judgment) IT-95-14/2-T (26 February 2001) [115]; Prosecutor v Kordic and Cerkę. (Appeal Judgment) IT-95-14/2-A (17 December 2004) [361]; Prosecutor $v$ Naletilić and Martinović (Trial Judgment) IT-98-34-T (31 March 2003) [198]; Prosecutor $v$ Prlic et al (Trial Judgment) IT-04-74-T (29 May 2013) vol 1 [86(a)].

49 See, eg, M Koskenniemi and P Leino, 'Fragmentation of International Law? Postmodern Anxieties' (2002) 15 LJIL $553,564-67$.

${ }^{50}$ Jorritsma (n 17) _.

${ }^{51}$ Ibid

52 Ibid

${ }^{53} \mathrm{Ibid}$

54 One of the present authors has recently argued elsewhere in favour of decoupling the law of State responsibility from conflict qualification under IHL: see K Mačák, Internationalized Armed Conflicts in International Law (OUP 2018) $44-47$.

55 See ILC ASR (n 37) Art 55.

56 Jorritsma (n 17) _.
} 
The next article, authored by Dr Antal Berkes, ${ }^{57}$ then turns to the notion of due diligence, the classical understanding of which places it at the outer bounds of the law of State responsibility. ${ }^{58}$ In other words, even if particular injurious conduct is not attributable to a State, that State may still be responsible for its own failure to prevent or punish that conduct-i.e., for failing to comply with its obligation of due diligence. ${ }^{59}$ Against this backdrop, Dr Berkes's article explores the impact that IHL has had on the development of the standard of due diligence in international law.

At the outset, he shows that the modern-day concept of due diligence can be traced back to specific IHL-based obligations of neutral States and occupying powers originating in the $19^{\text {th }}$ and early $20^{\text {th }}$ centuries. ${ }^{60}$ This analysis provides an important historical context to our understanding of this standard and its role in modern international law. Dr Berkes argues that once the standard had been established in general international law, it then influenced the interpretation of those rules of IHL that impose due diligence obligations, the first and foremost among them being the obligation to respect and ensure respect for IHL. ${ }^{61}$

He further analyses factors that determine the required degree of due diligence in a given situation, including territorial control, influence over the acting entity, and available technical capabilities. In this regard, he contends that IHL has 'deterritorialized' due diligence in the sense that it has extended the standard to situations in which States control foreign territory (e.g. during belligerent occupation). ${ }^{62}$ Overall, Dr Berkes recognizes that the interplay of these factors leaves States with considerable flexibility in performing their obligations. However, he argues that States must always do so by respecting what he describes as 'the raison d'etre' of that flexibility, namely the aim to alleviate human suffering during armed conflict. ${ }^{63}$

Finally, he examines the range of duty-bearers who are subject to the due diligence obligations. Although due diligence has traditionally been understood as a corollary of State sovereignty, ${ }^{64} \mathrm{Dr}$ Berkes shows that many obligations under IHL now impose the standard also on non-State actors including individuals, organized armed groups, and international organizations, and he explores the different legal effect that due diligence has on these entities as contrasted with States. ${ }^{65}$ All in all, his article shows the potential for cross-pollination between IHL and general international law through the lens of a single yet highly adaptable legal concept.

While State sovereignty has featured prominently in several of the preceding articles, the final contribution by Mr Rogier Bartels makes this concept its focal point. ${ }^{66}$ Specifically, Mr Bartels explores the relationship between the notion of sovereignty and the development of IHL. His

\footnotetext{
${ }^{57}$ Berkes (n 14).

58 See generally RY Jennings and A Watts (eds), Oppenheim's International Law (9th edn, Longman 1992) 549-54.

${ }^{59}$ See, eg, Janes et al (USA) v United Mexican States (1925) 4 RIAA 82, 86 (' $[\mathrm{f}$ a State shows serious lack of diligence in apprehending and/or punishing culprits, its liability is a derivative liability, ... rendering the State responsible for the very consequences of the individual's misdemeanor.').

${ }^{60}$ Berkes (n 14) _.

${ }^{61}$ Ibid _; see also GCs, Common Art 1; AP I, Art 1(1); J-M Henckaerts and L Doswald-Beck (eds), Customary International Humanitarian Law (CUP 2005) rule 139.

62 Berkes (n 14) _.

${ }^{63} \mathrm{Ibid}$

${ }^{64} \mathrm{See}$, eg, Island of Palmas case (Netherlands v US A) (Award) (1928) 2 RIAA 829, 839 ('Territorial sovereignty ... involves the exclusive right to display the activities of a State. This right has as corollary a duty: the obligation to protect within the territory the rights of other States[.]').

${ }^{65}$ Berkes (n 14) _.

${ }^{66}$ Bartels (n 14).
} 
overall argument is that the gradual process of introducing constraints to State sovereignty has been strongly catalysed by the conduct and outcome of armed conflicts.

Mr Bartels begins by noting that the enduring distinction in IHL between IACs and noninternational armed conflicts (NIACs) corresponds to the two main facets of sovereignty: while States agreed to constrain their external sovereignty by adopting extensive rules governing interState wars, they were much less willing to allow international law to encroach on their internal sovereignty in quelling domestic uprisings. ${ }^{67}$

However, in Mr Bartels' retelling, the history of war is a history of growing limitations on States' freedom to conduct themselves as they please. The main milestones are well-known: the prosecution by Germany of its own nationals for violations of IHL after World War I; the adoption of Common Article 3 to the Geneva Conventions in 1949; the growth of treaty rules specifically applicable in NIACs during the Cold War; ${ }^{68}$ the 'revolutionary' Tadic ruling in $1995{ }^{69}$ and so on. He then adds two newer case studies, exploring the impact on sovereignty that was brought about by the recent erosion of the requirement of consent to humanitarian assistance and by the emerging concept of 'transnational armed conflict'. ${ }^{70}$

Overall, Mr Bartels' principal contribution is in linking each of these historical developments with the changing notion of sovereignty, and this panoramic view allows him to draw the conclusion that even though States have gradually accepted many new limitations, they have simultaneously succeeded in preserving the key importance of sovereignty itself. On that basis, he summarizes that although it would be too soon to sound the death knell for sovereignty, one cannot deny the transformation that this concept has undergone in the recent past, much of it effectuated precisely by developments in the area of IHL. ${ }^{71}$

\section{Concluding remarks}

It was noted at the outset that there is a disconnect between the historically central role of IHL in the development of public international law and the now vast diversification of specialised areas of international law. The articles in this symposium have sought to elaborate on this by considering the relationship between IHL and certain fundamental features of general international law. Together, they reveal a fascinating and complex web of interactions between IHL and public international law, that is, between the specific and the general.

This analysis is very much intended as a starting point rather than an exhaustive review. In addition to offering insight into this relationship, it is hoped that it will also encourage an integrationist approach to IHL and many of the most pressing issues in the regulation of armed conflict. In so doing, one can then recognise IHL's place as firmly embedded within public international law and thus benefiting from a well-developed normative environment that can additionally provide insight into issues arising across different fields.

\footnotetext{
${ }^{67}$ Ibid

${ }^{68}$ See, in particular, Protocol Additional to the Geneva Conventions of 12 August 1949, and relating to the Protection of Victims of Non-International Armed Conflicts (Protocol II) (signed 12 December 1977, entered into force 7 December 1978) 1125 UNTS 609.

69 Prosecutorv Tadić (Decision on Jurisdiction) IT-94-1-AR72 (2 October 1995).

${ }^{70}$ Bartels (n 14) _.

${ }^{71}$ Ibid
} 